\title{
EKSISTENSI PESANTREN DARUU ATTAUHID MUARO KUMPEH - MUARO JAMBI TERHADAP PERUBAHAN SOSIAL KEAGAMAAN MASYARAKAT
}

\section{Edy Kusnadi}

Fakultas Ushuluddin IAIN STS Jambi

Email: edykusnadi2008@yahoo.co.id

\begin{abstract}
This study reveals how the existence of pesantren Daruu Attauhid in the village of Muara Kumpeh Kumpeh District of Ulu Muaro Jambi to social change around. As for the problem of this research is how the characteristics of pesantren Daruu Attauhid, then how the relationship pesantren Daruu Attauhid with surrounding communities, and how changes in social and religious communities around the schools where the Attauhid Daruu. Based on observations and interviews, found information that the learning is done at the boarding school was organized by non-classical or classical. The shape of the state of religious social changes that happened is that the state of religious social being quite religious.
\end{abstract}

\begin{abstract}
Abstrak
Penelitian ini mengungkapkan bagaimana eksistensi pesantren Daruu Attauhid di Desa Muaro Kumpeh Kecamatan Kumpeh Ulu Kabupaten Muaro Jambi terhadap perubahan sosial masyarakat sekitar. Adapun yang menjadi permasalahan dalam penelitian ini adalah bagaimana karakteristik pesantren Daruu Attauhid, kemudian bagaimana hubungan pesantren Daruu Attauhid dengan Masyarakat sekitar, dan bagaimana perubahan sosial keagamaan masyarakat sekitar dengan keberadaan pesantren Daruu Attauhid tersebut. Dari hasil pengamatan dan wawancara, didapati informasi bahwa pembelajaran yang dilakukan pada pondok pesantren ini diselenggarakan dengan cara non-klasikal atau dengan klasikal. Adapun bentuk perubahan keadaan sosial keagamaan yang terjadi adalah bahwa keadaan sosial keagamaan menjadi cukup religius.
\end{abstract}

Kata Kunci: Pesantren, Masyarakat, Perubahan Sosial Keagamaan

TAJDID vol. XV, No. 2, Juli - Desember 2016|165 


\section{Pendahuluan}

Pesantren memiliki basis sosial yang jelas, karena keberadaannya menyatu dengan masyarakat. Pada umumnya, pesantren hidup dari, oleh, dan untuk masyarakat itu sendiri. Oleh karenanya keberadaan pesantren ditengah-tengah masyarakat sedikit banyak mempunyai pengaruh terhadap kehidupan sosial masyarakat sekitar. Tantangan terbesar dalam menghadapi globalisasi dan modernisasi adalah pemberdayaan sumber daya manusia (SDM) dan ekonomi. Dalam kehidupan telah terjadi transformasi di semua segi terutama sosial dan budaya yang sangat cepat dan mendasar pada semua aspek kehidupan manusia. Berbagai perubahan tersebut menuntut sikap mental yang kuat, efisiensi, produktivitas hidup dan peran serta masyarakat.

Dua hal tersebut (SDM dan pengaruh sosial keagamaan) harus diarahkan pada pembentukan kepribadian, etika dan spritual yang nyata. Sehingga ada perimbangan antara keduniawian dan keagamaan. Dengan perkataan lain pesantren harus dapat turut mewujudkan manusia yang IMTAQ (beriman dan bertaqwa), yang berilmu dan beramal dan juga manusia modern peka terhadap realitas sosial kekinian, dan mampu terintegrasi dalam glabalisasi. Hal tersebut sesuai dengan kaidah "al mubafadotu 'ala qodimish sholih wal akbdu bi jadidil ashlab" (memelihara perkara lama yang baik dan mengambil perkara baru yang lebih baik). Langkah awal yang perlu di lakukan pesantren adalah komitmenya dalam menerapkan"Tri Dharma Pesantren" yakni: pendidikan, penelitian dan pengabdian masyarakat. Hal ini sebagai langkah integrasi-nya pesantren dalam memerankan fungsinya di masyarakat luas. Sehingga pesantren tidak hanya melahirkan agamawan saja, tetapi juga agamawan yang "luwes" inklusif, mempunyai jiwa sosial-kemasyarakatan serta kepribadian mandiri dan intrepreneurship. ${ }^{1}$

Namun sekarang nampaknya pesantren telah menunjukan peranya di masyarakat dan menepis anggapan - anggapan yang seolah-olah memojokkan pendidikan pesantren dalam hal ini madrasah orang beranggapan bahwa lulusan atau alumni madrasah hanyalah bisa berfatwa dan mengajari ngaji saja, bahkan sekarang sebuah anggapan itu sudah bergeser. Alumni-alumni pesantren sudah

1 Khoirul Ihwanudin. Peran Pesantren Terhadap Perubahan Sosial Masyarakat. Di akses https://pondpestalhidayah.wordpress.com /2011/06/10/peran-pesantren-terhadap-perubahan-sosial-masyarakat/ 4 Agustus 2015.

166 | TAJDID vol. XV, No. 1, Januari - Juni 2016 
biasa "beradaptasi" dan "berintegrasi" dengan dunia luar, mulai berkecimpung didunia pendidikan, politik, sosial-budaya, kewirausahaan dan lain sebagainya. Bahkan dalam dunia pendidikan sekarang ini banyak yang mengadopsi dari pendidikan pesantren termasuk full day school, berbusana muslim serta pendidikan berbasis karakter $^{2}$, pendidikan pesantren mengajarkan keteladanan sebagaimana kata pepatah" satu keteladanan lebih berarti daripada sejuta araban".

Pada sisi lain Pesantren adalah sebuah komunitas peradaban dan sering dipandang sebelah mata karena lebih banyak mengurusi soal ukhrowiyah yang tidak diimbangi dengan duniawiyah. Pesantren menjadi tempat untuk pembinaan moral-spiritual, kesalehan seseorang dan pembelajaran ilmu-ilmu agama Islam. Sering pula dicerca sebagai pusat kehidupan fatalis, karena memproduksi kehidupan zuhud yang mengabaikan dunia materi. Padahal yang dilakukan oleh orang pesantren itu merupakan sebuah kesederhanaan dan kesahajaan dalam menaungi sebuah kehidupan di dunia dan berusaha "menabung" untuk menggapai akhiratnya.

Namun sekarang sebuah anggapan itu sudah agak bergeser. Alumni-alumni pesantren sudah biasa "beradaptasi" dengan dunia luar, mulai berkecimpung di dunia pendidikan, politik, sosial-budaya, kewirausahaan dan lain sebagainya. Ziemek memandang bahwa pesantren merupakan pusat perubahan di bidang pendidikan, politik, budaya, sosial, dan keagamaan. ${ }^{3}$

Keberadaan pesantren di tengah-tengah masyarakat mempunyai makna sangat strategis, apalagi jika pesantren ini memiliki kurikulum pendidikan umum. Lembaga pesantren yang berakar pada masyarakat, merupakan kekuatan tersendiri dalam membangkitkan semangat dan gairah masyarakat untuk meraih kemajuan menuju ke arah kehidupan yang makin sejahtera. Apalagi dalam menghadapi era globalisasi yang berdampak kepada berbagai perubahan terutama di bidang ekonomi maupun sosial-budaya, dan perlu juga memperhatikan gerakan pesantren dalam mengapresiasikan arus globalisasi dan modernisasi yang berlangsung demikian kuatnya saat ini.

${ }^{2}$ Budhy Munawar-Rahman. Pendidikan Karater; Pendidikan Menghidupkan Nilai Untuk Pesantren, Madrasah, dan sekolah. 2015.

${ }^{3}$ Manfred Ziemek, Pesantern Dalam Perubahan Sosial, (Jakarta : Perhimpunan Pengembangan Pesantren dan Masyarakat, 1986), 2

\section{TAJDID vol. XV, No. 2, Juli - Desember 2016 | 167}


Pesantren memiliki basis sosial yang jelas, karena keberadaannya menyatu dengan masyarakat. Pada umumnya, pesantren hidup dari, oleh, dan untuk masyarakat. Hal ini menuntut adanya peran dan fungsi pondok pesantren yang sejalan dengan situasi dan kondisi masyarakat, bangsa, dan negara yang terus berkembang. Dan sebagian yang lain sebagai suatu komunitas, pesantren dapat berperan menjadi penggerak bagi upaya peningkatan kesejahteraan masyarakat, khususnya masyarakat yang berada di sekitarnya. Mengingat pesantren merupakan kekuatan sosial yang jumlahnya cukup besar. Secara umum, akumulasi tata nilai dan kehidupan spiritual di pesantren pada dasarnya adalah lembaga tafaqquh fiddin (pendalaman dan penguasaan ilmu agama) yakni dengan melestarikan ajaran agama Islam serta mengikutkannya pada konteks sosial-budaya.

Untuk mentransformasikan pesantren berperan dalam pemberdayaan masyarakat, maka perlunya langkah-langkah khusus yang dilakukan oleh lembaga tertentu dalam memproduksi santrisantri sebagai "Agent of Change" yang peka terhadap arus modernisasi dan masalah sosial-budaya dalam masyarakat, sehingga terjalinya keharmonisan antara masyarakat terutama sekali masyarakat di sekitar pesantren itu sendiri. ${ }^{4}$ Kemudian sedikit banyak dapat berpengaruh terhadap pola kehidupan sosial keagamaan masyarakat sekitar.

Keberadaan pesantren di tengah-tengah masyarakat sebagai salah satu agen perubahan sosial keagamaan, juga hendaknya pada sisi tata kehidupan juga dijadikan sebagai rool model dalam keseharian baik itu dari segi membina hubungan antar sesama manusia maupun terhadap Tuhan sang pencipta. Namun jika pesantren tersebut tidak mampu untuk berkiprah dan mengambil bagian dalam masyarakat maka pesantren tersebut dianggap sebagi hanya melihat dari satu sisi saja yaitu membina hubungan dengan Tuhan saja. Dengan kata lain hubungan dengan manusia belum terbina dengan baik.

Di desa Muaro Kumpeh Kecamatan Muaro Jambi juga terdapat suatu pesantren yang berada di tengah-tengah perkampungan. Pesantren tersebut berdiri sejak tahun 2005 lalu, dan telah banyak menghasilkan para lulusannya. Jauh sebelum itu masyarakat sekitanya kehidupan beragama dan sosialnya masih belum begitu baik hal tersebut sebagaimana pernyataan dari beberapa tokoh masyarakat

${ }^{4}$ Sihabuddin. Pesantren sebagai Agent of Change. Di akses https:// ayikngalah.wordpress.com/2011/07/21/peran-pesantren-dalam-pemberdayaanmasyarakat/ 4 Agustus 2015. 
mengatakan bahwa sebelum berdirinya pesantern itu masih banyak para remajanya yang tidak tau dan mengenal ilmu agama. Pada di sisi lain situasi sosialnya dulu rentan dengan konflik, baik sesama warga setempat maupun dengan warga laur kampung. Berdasarkan keadaan demikian peneliti ingin melihat lebih jauh dan mendalam terhadap peran pesantren tersebut di tengah-tengah masyarakat, serta pengaruh keberadaannya apakah merubah keadaan sosial keagamaan masyarakat setempat atau tidak.

\section{Pondok Pesantren}

Pesantren adalah sebuah kawasan yang khas yang ciri-cirinya tidak dimiliki oleh kawasan yang lain. Karenanya tidak berlebihan jika Abdurrahman Wahid menyebut sebagai sub-kultur tersendiri. Adapun unsur-unsur yang terdapat dalam sistem pendidikan pesantren secara tradisional yang menjadikannya khas adalah kiyai, santri, masjid, pondok dan pengajaran kitab-kitab klasik. ${ }^{5}$

Secara garis besar, tipologi pesantren bisa dibedakan paling tidak menjadi tiga jenis, walaupun agak sulit untuk membedakan secara ekstrim diantara tipe-tipe tersebut yaitu salafiyahh (tradisional), khalafiyah (modern) dan terpadu. ${ }^{6}$ Salafiyah adalah tipe pesantren yang hanya mengajarkan ilmu-ilmu agama Islam, atau kitab-kitab klasik yang ditulis oleh para ulama terdahulu. Metode pengajaran yang digunakan hanyalah metode bandongan, sorogan, hafalan, dan musyawarah.

Pondok pesantren sebagai institusi pendidikan bertugas menyediakan layanan untuk kepentingan masyarakat umum. Ada dua hal yang selalu menjadi pertanyaan mendasar yang berkaitan dengan mutu pendidikan. Pertama, apa yang menjadi produk pendidikan. Kedua, siapa yang dimaksud dengan pelanggan pendidikan. ${ }^{7}$

Pesantren akan tetap eksis sebagai lembaga pendidikan Islam yang mempuyai visi mencetak manusia-manusia unggul. Prinsip pesantren adalah al mubafarha 'ala al qadim al shalih, wa al akhd₹u al jadid al ashlah, yaitu tetap memegang tradisi yang positif, dan mengimbangi

5 Zamakhsyari Dhofier, Tradisi Pesantren: Studi Tentang Pandangan Hidup Kiyai (Jakarta: LP3ES, 1981), 44.

6 Wahjotomo, Perguruan Tinggi Pesantren, Pendidikan Alternatif Masa Depan (Jakarta: Gema Insani Press, 1997), 45.

7 Kasful Anwar. Kepemimpinan Pesantren Menawarkan Model Kepemimpinan Kolektif dan Responsif. (Jambi: Sulthan Thaha Press. 2011),84.

TAJDID vol. XV, No. 2, Juli - Desember 2016|169 
dengan mengambil hal-hal baru yang positif. Perseolan-persoalan yang berpautan dengan civic values akan bisa dibenahi melalui prinsipprinsip yang dipegang pesantren selama ini dan tentunya dengan perombakan yang efektif, berdaya guna, serta mampu memberi kesejajaran sebagai ummat manusia (al musawah baina al nas). ${ }^{8}$

Sebagai lembaga dan pusat pendidikan Islam, pesantren bertujuan tidak semata untuk memperkaya pikiran santri dengan teksteks dan penjelasan-penjelasan Islami, tetapi untuk meninggikan moral, melatih dan mempertinggi semangat, menghargai nilai-nilai spiritual dan kemanusiaan, mengajarkan sikap tingkah laku jujur dan bermoral, dan menyiapkan murid untuk hidup sederhana dan bersih hati. Setiap murid diajar agar menerima etik agama di atas etik-etik yang lain.?

Menurut Amin Haedari, lahirnya suatu pesantren berawal dari beberapa elemen dasar yang selalu ada di dalamnya. Setidaknya ada lima elemen pesantren, antara satu dengan yang lainnya tidak dapat dipisahkan. Kelima elemen tersebut meliputi kyai, santri, pondok, masjid, dan pengajaran kitab-kitab klasik, atau yang sering disebut dengan kitab kuning. ${ }^{10}$ Kelima elemen tersebut merupakan ciri khusus yang dimiliki pesantren dan membedakan pendidikan pondok pesantren dengan lembaga pendidikan dalam bentuk lain.

Permasahan seputar pengembangan model pendidikan pondok pesantren dalam hubungannya dengan peningkatan kualitas sumberdaya manusia (buman resources) merupakan isu aktual dalam arus perbincangan kepesantrenan kontemporer. Maraknya perbincangan mengenai isu tersebut tidak bisa dilepaskan dari realitas empirik keberadaan pesantren dewasa ini yang dinilai kurang mampu mengoptimalisasi potensi yang dimilikinya. Setidaknya terdapat dua potensi besar yang dimiliki pesantren yaitu potensi pendidikan dan pengembangan masyarakat. ${ }^{11}$

8 Kasful Anwar, Kepemimpinan Pesantren Menawarkan Model Kepemimpinan Kolektif dan Responsif, 89.

9 Mubtarom HM dalam Ismail et.al. (ed), Dinamika Pesantren dan Madrasah, (Yogyakarta :: Pustaka Pelajar \& Semarang: Fakultas Tarbiyah IAIN Wali Songo, 2002), 44

10 Amin Haedari, et.al. Masa Depan Pesantren dalam Tantangan Modernitas dan Tantangan Komplesitas Global. (Jakarta: IRD Press. 2005), 25.

${ }^{11}$ Sulthon Masyhud dan Moh. Khusnurdilo. Op. Cit. hal. 17. 


\section{Pesantren Sebagai Agen Perubahan Sosial Keagamaan}

Perubahan sosial merupakan perubahan kehidupan masyarakat yang berlangsung terus-menerus dan tidak akan pernah berhenti, karena tidak ada satu masyarakatpun yang berhenti pada suatu titik tertentu sepanjang masa. Walaupun bentuk dan jenis perubahan tersebut ada yang cepat dan ada yang lambat. Perubahan sosial juga merupakan perubahan yang terjadi karena adanya ketidak sesuaian di antara unsur-unsur sosial yang berbeda di dalam kehidupan masyarakat, sehingga menghasilkan pola kehidupan yang baru (berbeda dengan pola kehidupan sebelumnya). Perubahan sosial mencakup perubahan dalam nilai - nilai sosial, norma-norma sosial, susunan lembaga kemasyarakatan, pelapisan sosial, kelompok sosial, interaksi sosial, pola-pola perilaku, kekuasaan dan wewenang, pemahaman dan perubahan tingkah laku dalam norma beragama, serta berbagai segi kehidupan masyarakat lainnya. Berikut ini merupakan definisi perubahan sosial yang dikemukakan oleh para Sosiolog yakni:

a)John Lewis Gillin dan John Philip Gillin : Perubahan sosial adalah suatu variasi dari cara hidup yang diterima, akibat adanya perubahan kondisi geografis, kebudayaan material, komposisi penduduk, ideologi, maupun karena adanya difusi dan penemuan baru dalam masyarakat.

b)William F. Ogburn : Perubahan sosial menekankan pada kondisi teknologis yang menyebabkan terjadinya perubahan pada aspek-aspek kehidupan sosial, seperti kemajuan ilmu pengetahuan dan teknologi yang sangat berpengaruh terhadap pola berpikir masyarakat. Melihat begitu luasnya cakupan perubahan sosial yang terjadi dalam masyarakat, maka untuk mengetahui suatu perubahan sosial dapat dilakukan dengan jalan melakukan pengamatan yang cermat terhadap suatu masyarakat dan membandingkannya dengan keadaan masyarakat tersebut pada masa lampau/sebelumnya, untuk memahami perbedaan keadaannya.

\section{Perubahan Sosial}

Salah satu teori perubahan sosial adalah teori Fungsionalis (Functionalist Theory). Penganut teori ini memandang setiap elemen masyarakat memberikan fungsi terhadap elemen masyarakat lainnya. Perubahan yang muncul di suatu bagian masyarakat akan menimbulkan perubahan pada bagian yang lain pula. Perubahan 
dianggap mengacaukan keseimbangan masyarakat. Proses pengacauan itu berhenti pada saat perubahan tersebut telah diintegrasikan ke dalam kebudayaan ( menjadi cara hidup masyarakat).

Oleh sebab itu menurut teori ini unsur kebudayaan baru yang memiliki

fungsi bagi masyarakat akan diterima, sebaliknya yang disfungsional akan ditolak. Menurut sosiolog William Ogburn, meskipun unsur unsur masyarakat saling berhubungan, beberapa unsurnya bisa berubah sangat cepat sementara unsur yang lain berubah secara lambat, sehingga terjadi apa yang disebutnya dengan ketertinggalan budaya ( cultural lag) yang mengakibatkan terjadinya kejutan sosial pada masyarakat, sehingga mengacaukan keseimbangan dalam masyarakat. Menurutnya, perubahan benda-benda budaya materi / teknologi berubah lebih cepat daripada perubahan dalam budaya non materi / sistem dan struktur sosial. ${ }^{12}$ Dengan kata lain, kita berusaha mengejar teknologi yang terus berubah, dengan mengadaptasi adat dan cara hidup kita untuk memenuhi kebutuhan teknologi.

\section{Bentuk-Bentuk Perubahan Sosial}

Berbagai macam bentuk-bentuk perubahan sosial antaranya adalah perubahan sosial yang direncanakan. Perubahan Sosial yang dikehendaki atau direncanakan merupakan perubahan yang diperkirakan atau direncanakan terlebih dahulu oleh pihak-pihak yang akan mengadakan perubahan di dalam masyarakat. Pihak-pihak yang menghendaki perubahan dinamakan Agent of change (agen perubahan), yaitu seseorang atau sekelompok orang yang telah mendapat kepercayaan masyarakat sebagai pemimpin dari satu atau lebih lembaga - lembaga kemasyarakatan, serta memimpin masyarakat dalam mengubah sistem sosial.

Suatu perubahan yang dikehendaki atau yang direncanakan selalu berada di bawah pengendalian serta pengawasan Agent of change tersebut. Cara-cara mempengaruhi masyarakat dengan sistem yang teratur dan direncanakan terlebih dahulu dinamakan rekayasa sosial ( sosial engineering) atau yang biasa disebut sebagai perencanaan sosial. ${ }^{13}$ Melalui pendidikan dan pengajaran merupakan salah satu model perencanaan perubahan sosial dan keagamaan dalam masyarakat.

12 Henslin, James M, Essential of Sociology : A Down-to-Earth Approach (Sosiologi dengan Pendekatan Membumi). (Jakarta: Penerbit Erlangga.2007).

13 Ibid. 
Sehingga sedikit banyak keberadaan pesantren di tengah-tengah masyarakat dapat mempengaruhi pola kehidupan dalam masyarakat. Pesantren adalah merupakan salah satu wadah untuk membuat perubahan sosial yang direncanakan.

Perubahan dan perkembangan itu bisa ditilik dari dua sudut pandang Pertama, pesantren mengalami perkembangan kuantitas luar biasa dan menakjubkan, baik di wilayah rural (pedesaan), sub-urban (pinggiran kota), maupun urban (perkotaan). Cukup banyaknya jumlah pesantren dengan berbagai corak ini selayaknya menjadi catatan pemerintah terutama dalam rangka realisasi gerakan pendidikan untuk semua, Kedua. Menyangkut penyelenggaraan pendidikan. Dalam aspek kurikulum, misalnya, pesantren tidak lagi hanya memberikan mata pelajaran ilmu-ilmu keislaman, tetapi juga ilmu-ilmu umum yang diakomodasi dari kurikulum pemerintah, seperti matematika, fisika, biologi, Bahasa Inggris dan sejarah.

\section{Karateristik Pondok Pesantren Daruu Attauhid di Desa Muaro Kumpeh Kec. Kumpeh Ulu Kab. Muaro Jambi.}

Berdasarkan hasil pengamatan dan wawancara penulis terhadap unsur pimpinan, pengelola dan pengajar, maka penulis mendapatkan informasi bahwa elemen-elemen yang terdapat pada pondok Pesantren Daruu Attauhid adalah bahwa Pesantren Daruu Attauhid adalah tergolong pada pesantren Salafiyah sehingga kurikulum pembelajarannya tidak mengikuti aturan atau pedoman yang telah ditetapkan pemerintah. Pondok Pesantren Salafiyah adalah pondok pesantren yang menyelenggarakan pengajaran Al-Quran dan ilmuilmu agama Islam yang kegiatan pendidikan dan pengajarannya sebagaimana yang berlangsung sejak awal pertumbuhannya. Pembelajaran (pendidikan dan pengajaran) yang ada pada pondok pesantren ini dapat diselenggarakan dengan cara non-klasikal atau dengan klasikal. Jenis pondok ini pun dapat meningkat dengan membuat kurikulum sendiri, dalam arti kurikulum ala pondok pesantren yang bersangkutan yang disusun sendiri berdasarkan ciri khas yang dimiliki oleh pondok pesantren.

Selain dari pada itu di pesantren Daruu Attauhid terdapat beberapa unsur, hal tersebut juga sejalan dengan pandangan Amin 
Haidari , ${ }^{14}$ bahwa terdapat beberapa unsur lain didalam pesantren antaranya:

1. Kyai (Ustadz).

Kyai merupakan elemen yang paling esensial dari suatu pesantren dan sering biasanya merupakan pendirinya. Sudah sewajarnya bahwa pertumbuhan suatu pesantren semata-mata bergantung kepada kemampuan pribadi kyainya dalam penguasaan ilmu agama dan karismatiknya. Menurut Imam Banawi sebagaimana dikutip oleh Yasmadi, keberadaan seorang kyai dalam lingkungan sebuah pesantren laksana jantung bagi kehidupan manusia di pesantren. ${ }^{15}$

Begitu juga dengan pesantren Daruu Attauhid ini, juga memiliki seorang kyai yang bernama Ustadz Salahuddin yang berperan sebagai pendiri sekaligus pengajar pada pesantren tersebut. Keberadaannya dalam pesantren merupakan hal yang mutlak bagi pesantren tersebut, sebab dia adalah tokoh sentral yang memberikan pengajaran, karena beliau menjadi salah satu unsur yang paling dominan dalam kehidupan pesantren.

\section{Pondok}

Suatu pondok pesantren pada dasarnya adalah sebuah asrama pendidikan Islam tradisional di mana para siswanya tinggal bersama dan belajar di bawah bimbingan seorang (atau lebih) guru yang lebih dikenal dengan sebutan "kyai" atau "Ustad". Begitu juga pada pesantren Daruu Attauhid, nampak terlihat asrama untuk para santri tersebut berada dalam lingkungan pesantren. Tepatnya selang beberapa meter saja dari rumah Ustad Salahuddin. Kedekatan rumahnya dengan pondok membuat seakan-akan beliau selalu berada di kawasan pondok dan mempermudah pengawasan serta proses pembelajaran kepada para santrinya. Pentingnya pondok pesantren sebagai asrama para santri tergantung kepada jumlah santri baik yang berasal dari desa Muaro Kumpeh itu sendiri maupun yang berasal dari luar desa.

\section{Pengajar (Ustadz)}

14 Lihat. Amin Haedari, et.al. Masa Depan Pesantren dalam Tantangan Modernitas dan Tantangan Komplesitas Global. (Jakarta: IRD Press. 2005) , 25.

15 Yasmadi, Modernisasi Pesantren, Krituk Nurcholish Madjid terhadap Pendidikan Islam (Tradisional, Edisi Revisi, Ciputat: Quantum Teaching, 2002), 63. 
Pesantren Ashabul Khahfi ini dipimpin oleh Ustaz Salahuddin. Beliau adalah alumni dari pondok pesantren Nurul Iman seberang Kota Jambi. Kemudian beliau dibantu oleh santri-santri senior yang terdapat di Pesantren Ashabul Kahfi, mereka hanya bersifat sukarela, tidak mengharapkan uang atau gaji dalam mengajarnya, sebab mereka sudah ditanamkan sifat keihlasan atau kesukarelaan atau dengan kata lain pengabdian terhadap agama. Namun berkat kepiawaian dan karismatik pemimpinya maka tidak sedikit para santri senior yang menawarkan diri untuk membantu mengajar di madrasah pondok pesantren tersebut walaupun mereka dan tidak sebagai pegawai negeri.

\section{Santri}

Peserta didik yang terdapat di pesantren ini adalah terdiri dari beberapa kategori pertama, setingkat dengan madrasah Ibtidaiyah, kedua remaja dan dewasa (ngaji kitab). Adapun santri dipesantren, tersebut terbagi atas 3 kelompok santri, yakni:

Santri reguler, yakni para santri madrasah yang berasal dari desa Muaro Kumpeh sendiri dan dari desa sekitarnya, seperti desa Pudak, Talang Duku dan Sejinjang. Proses belajarnya adalah sore hari dan seperti madrasah biasa pada umumnya. Murid-murinya tidak mondok atau nginap di pondok, melainkan pulang kerumah masing-masing. Santri ini adalah kususnya pada tingkatan Ibtidaiyah.

Santri mukmin, yaitu murid-murid yang berasal dari desa Muaro Kumpeh dan daerah lain dan menetap dan tinggal dalam pondok pesantren. Santri mukmin yang paling lama tinggal di pesantren tersebut biasanya merupakan satu kelompok tersendiri yang memegang tanggungjawab mengurusi kepentingan pesantren seharihari; mereka juga memikul tanggungjawab mengajar santri-santri muda tentang kitab-kitab dasar dan menengah. Santri ini khususnya pada tingkatan Tsanawiyah.

Santri kalong yaitu para santri yang berasal dari desa Muaro Kumpeh dan desa-desa di sekeliling pesantren, yang tidak menetap dalam pesantren. Untuk mengikuti pelajarannya di pesantren, mereka bolak-balik dari rumahnya sendiri. Pada santri kalong tersebut dibuat dalam dua kelompok. Kelompok pertama adalah belajar di pondok dan kelompok kedua belajarnya di rumah Ustad Salahuddin. Mengapa dibagi menjadi dua bagian, hal tersebut terlihat dari materi dan waktu pembelajarannya. Kalau pembelajarannya pada tahap ringan dan sedang maka dilakukan di pondok, dan dilaksanakan pada malam

TAJDID vol. XV, No. 2, Juli - Desember 2016 $\mid 175$ 
sabtu dan malam minggu. Tetapi pada pemebalajaran tinggi dan mendalam dilakukan di rumah Ustad Salahuddin, yaitu pada malam selasa dan malam sabtu. ${ }^{16}$

\section{Masjid}

Masjid adalah sebagai pusat kegiatan ibadah dan belajar mengajar. Pondok Pesantren Daruu Attauhid sebenarnya belum mempunyai masjid, tetapi masih berstatus musollah atau surau. Disitulah mereka malakukan proses pembelajaran. Walaupun demikian surau tersebutlah merupakan elemen yang tidak dapat dipisahkan dengan pesantren dan dianggap sebagai tempat yang paling tepat untuk mendidik para santri, terutama dalam praktek sembahyang lima waktu, khutbah dan sembahyang Jum'ah, dan pengajaran kitab-kitab Islam kuning. ${ }^{17}$ Jadi nyatalah bahwa proses pembelajaran di surau dan menganggap surau sebagai tempat yang paling tepat untuk menanamkan disiplin para murid dalam mengerjakan kewajiban sembahyang lima waktu, memperoleh pengetahuan agama dan kewajiban agama yang lain.

\section{Pengajaran Kitab Kuning.}

Berdasarkan hasil wawancara diatas terlihat bahwa di pesantren tersebut banyak memberikan pelajaran tentang Tauhid, ibadah, muamalah dan Tasawuf, yang berpandukan pada kitab-kitab klasik atau kitab kuning yang di cerna dan disesuaikan dengan konteks sekarang. Adapun kitab -kitab tersebut antaranya adalah Al-Hikam, Fathul Majid, Fathul Muin, Riadussalihin dan lain-lainnya. ${ }^{18}$ Mereka menerjamah kitab tersebut, bukanlah sekedar "membaca teks, tetapi juga memberikan pandangan-pandangan pribadi, baik mengenai isi maupun bahasa dari teks. Dengan kata lain, pembelajaran tersebut memberikan pula komentar atas teks sebagai pandangan pribadinya. Oleh karena itu, ustad tersebut haruslah menguasai tatabahasa Arab, literatur dan cabang-cabang pengetahuan agama Islam yang lain.

\section{Fasilitas dan Pembiayaan}

16 Atobri, wawancara dengan Peneliti pada 7 Desember 2015 di Desa Muaro Kumpeh.

17 Ibid.

18 Mahfuk, Wawancara dengan Peneliti pada 2 Desember 2015 di Desa Pudak. 
Adapun fasilitas cukup lengkap, pesantren ini memiliki ruang belajar dan asrama santri serta ada musollahnya, mereka juga memiliki alat transportasi mobil pesantren yang merupakan sumbengan donatur dari masyarakat. Begitu juga dengan pembiayaan di pesantren ini. Pembiayaan operasional pesantren ini adalah sepenuhnya bersumber dari infak dan sedekah masyarakat dan donatur, walaupun dalam regulasinya bahwa para santri tidak dipungut biaya. Kecuali santri yang menginap, mereka dikenakan biaya makan sebesar Rp 200.000 (dua ratus ribu rupiah) sebulan. Jadi tidak ada bantuan pemerintah dalam operasional keuangan pesantren. Ini bukan berarti pemerintah tidak mau membantu ataupun tidak peduli tetapi ini merupakan kebijakan pengurus pesantren tersebut. ${ }^{19}$

\section{Hubungan Sosial Pondok Pesantren Daruu Attauhid dengan Masyarakat Sekitar}

\section{Pendidikan Madrasah Ibtidaiyah}

Di pesantren Daruu Attauhid pimpinan Ustaz Solahuddin Desa Muaro Kumpeh juga mengedepankan pendidikan anak-anak yang tak lain adalah pendidikan Madrasah Ibtidaiyah. Sekilas jika dilihat ini adalah sejenis madrasah biasa, namun setelah peneliti melakukan pengamatan dan wawancara mendalam maka ditemukan bahwa ada hal yang cukup unik yakni walaupun tak jauh dari keberadaan pesantren tersebut ada sebuah madrasah Ibtidaiyah juga yang bernama Madrasah Nurul Huda, namun kebanyak dari orang tua lebih memilih untuk menyekolahkan anak-anak mereka di Madrasah pesantren Daruu Attauhid tersebut. Berdasarkan wawancara dengan salah seorang wali murid bahwa mereka lebih meyakini terhadap pendidikan yang dilakukan pada pesantren Daruu Attauhid, karena lebih bagus dan mendalam. ${ }^{20}$

Hal ini dikarenakan menurut hasil wawancara bahwa materi, dan cara yang di pakai oleh pesantren tersebut cukup mendalam serta di pengaruhi juga oleh figur sang Ustaz sebagai pimpinan podok pesantren tersebut. Inilah yang menyebabkan para orang tua lebih

19 Mahfuk, wawancara dengan Peneliti pada 2 Desember 2015 di Desa Muaro Kumpeh.

20 Bujang, Wawancara dengan Peneliti pada 5 Desember 2015 di desa Muaro Kumpeh.

TAJDID vol. XV, No. 2, Juli - Desember 2016 |177 
memilih untuk menyekolahkan anak mereka di Madrasah pesantren, ketimbang di madrasah lainya. ${ }^{21}$

Begiti juga menurut salah seorang guru terdapat 87 orang anak yang terdaftar sebagai siswa yang berasal dari desa Muaro Kumpeh itu sendiri dan dari desa-desa yang ada di sekitarnya, seperti desa Pudak, Talang Duku, dan Kelurahan Sejinjang. ${ }^{22}$ Adapun pelaksanaan belajarnya dilakukan pada sore hari dan di kelompokan dalam dua kelompok.

\section{Pendidikan Tsanawiyah}

Tidak jauh berbeda dengan tingkat Madrasah Ibtidaiyah, pada tingkat Madrasah Tsanawiyahnya juga cukup banyak peminatnya. Berdasarkan hasil pengamatan dan wawancara ditemukan bahwa pelaksanaan pembelajaran untuk tingkat Tsanawiyah dilakukan pada pagi hari. Namun kesemuanya siswa diwajibkan untuk tinggal dan mondok di sana. Pada pagi hari mereka belajar pelajaran biasa namun pada malamnya baru mereka belajar yang lebih mendalam lagi dan langsung diajar oleh Ustaz Salahuddin sendiri. Karena keterbatasan ruang belajar, maka pada waktu sore hari mereka tidak ada aktifita belajar, akan tetapi mereka diberi peluang untuk belajar sendiri atau melakukan aktifitas pondok atau ada sebahagian yang ikut mengajari anak-anak kembali melakukan proses pembelajaran.

\section{Pendidikan untuk Umum (Santri Kalong)}

Bagi orang awam mendengar istilah santri kalong adalah suatu ungkapan yang agak tabu, mengapa tidak, bahwa kalong dipersepsikan pada seekor hewan yang menyerupai kelelawar tetapi berukuran besar. Akan tetapi istilah ini diibaratkan padanya yakni suatu proses pengajian yang di adakan pada malam hari dan santrinya kebanyak adalah dari luar pondok pesantren yang datang dan tidak tinggal di dalam pondok pesantren.

Pada pelaksanaan pembelajaran tersebut yakni ustadz menggunakan beberapa metode pembelajaran antaranya metode wetonan atau bandongan. Kadang-kadang dengan metode sorogan. Metode weton atau bandongan ini adalah cara penyampaian ajaran

21 Tohir, Wawancara dengan Peneliti pada 2 Desermber 2015 di desa Muaro Kumpeh.

${ }^{22}$ Mu'is, Wawancara dengan salah seorang guru pada 3 Desember 2015 di Desa Muaro Kumpeh. 
materi kitab kuning di mana seorang guru, kyai, atau ustadz membaca dan menjelaskan isi ajaran/kitab kuning tersebut, sementara santri, murid atau siswa mendengarkan, memaknai dan menerima. Dalam metode ini, guru berperan aktif, sementara murid bersikap pasif. Dan biasanya dalam sistem wetonan ini sekelompok murid mendengarkan seorang guru yang membaca, menerjemahkan, menerangkan dan seringkali mengulas buku-buku Islam dalam bahasa Arab. Setiap murid memperhatikan bukunya sendiri dan membuat catatan-catatan tentang kata-kata atau buah pikiran yang sulit. Kelompok kelas dari sistem ini disebut halaqah. Metode pengajaran tersebut dilakukan terhadap sekelompok santri untuk mendengarkan atau menyimak apa yang dibacakan oleh ustaz dari sebuah kitab. Santri dengan memegang kitab yang sama, masing-masing melakukan pendhabitan harakat kata lagsung di bawah kata yang dimaksud agar dapat membantu memahmi teks. ${ }^{23}$

\section{Keterlibatan Pesantren Terhadap Kegiatan dalam Masyarakat}

\section{Pesantren Sebagai Sarana Pendidikan Agama Islam bagi Masyarakat}

Pesantren adalah suatu lembaga pendidikan Agama Islam yang sangat tepat baik, bahkan konsep pendidikan sekarang banyak yang mengadopsi daripada bentuk atau model pendidikan dalam Pesantren. Dan sekarang nampaknya pesantren telah menunjukan peranya di masyarakat dan menepis anggapan- anggapan yang seolah memojokkan pendidikan pesantren dalam hal ini madrasah orang beranggapan bahwa lulusan atau alumni madrasah hanyalah bisa berfatwa dan mengajari ngaji saja, Dan sekarang sebuah anggapan itu sudah bergeser. Alumni-alumni pesantren sudah biasa "beradaptasi" dengan dunia luar, mulai berkecimpung di dunia pendidikan, politik, sosial-budaya, kewirausahaan dan lain sebagainya.

Bahkan dalam dunia pendidikan sekarang ini banyak yang mengadopsi dari pendidikan pesantren termasuk full day school, Berbusana muslim serta pendidikan berbasis karakter, pendidikan pesantren mengajarkan keteladanan sebagaimana kata pepatah" satu keteladanan lebih berarti daripada sejuta araban".

23 Faiqoh, Pondok Pesantren dan Madrasah Diniyab: Pertumbuban dan perkembangannya, (Jakarta: Depag RI, 2004), h. 39.

TAJDID vol. XV, No. 2, Juli - Desember 2016|179 
Sekarang ini menjadi lulusan pesantren atau madrasah menjadi sebuah kebanggaan tersendiri bagi orang tua dan masyarakat karena matang jiwa kemandirianya dan berperan di masyarakat,dalam realitas sekarang ini banyak pengangguran yang kebanyakan di isi oleh kelas menengah terpelajar ketidak berdayaan kelas terpelajar ini sebenarnya di akibatkan oleh sistem sebagai struktur pembelajaran yang telah membawa dampak pada alienasi (keterasingan) peserta didik terhadap dunia luar. Alienasi dalam kerangka tradisional di pahami bahwa peserta didik telah mempunyai persepsi sekolah atau lembaga pendidikan telah di anggap dapat menjanjikan kerja langsung, padahal perkembangan dalam dunia kerja begitu cepat melebihi nalar keilmuan yang di ajarkan di lembaga sekolah, maka ketika sudah terjadi hal seperti ini keputusasaanlah yang akan muncul.

\section{Partisipasi dalam Kegiatan Peringatan Hari Besar Islam}

Dalam peringatah hari-hari besar Islam seperti Maulid Nabi Muhammad Saw, Peringatan Isra'walmi'raj, Tahun Baru Hijriah, Nuzulul Qur'an dan sebagainya, bahwa peran dan partisipasi pesantren juga terlihat. Mereka mengikuti acara yang diadakan oleh masayarakat kampung, selain itu mereka juga mengadakan sendiri dan mengundang masyarakat desa Muaro umpeh tersebut. begitu juga dalam kepanitiaan ada sebahagian santri yang dilibatkan dan mengisi sebahagian acara yang berlangsung.

\section{Partisipasi dalam Kegiatan Hajatan}

Dalam acara hajatan, jika ada masyarakat sekitar yang mengadakan hajatan, baik itu acara rutin pengajian yasinan, atau acara syukuran dan bahkan acara hajatan perkawinan, para santri di pondok tersebut sebahagian besar diundang. Nampaklah mereka datang memenuhi undangan tersebut. Akan tetapi ada yang berbeda dari yang lain, selagi yang mempunyai hajatan tersebut dalam melakukan atau pelaksanaannya tidak mengadakan hiburan berupa organ Tunggal, mereka warga pesantren akan datang menghadiri. Dan jika tuan rumah mengadakan hajatan dan menampilkan organ tunggal atau hiburan sejenisnya maka warga pesantren tidak akan datang. Hal tersebut sudah merupakan ajaran dari Ustaz Salahuddin bahwa dia melarang jenis atau bentuk hiburan organ tunggal tersebut, jadi warga pesantren tidak ada yang datang.

180 | TAJDID vol. Xv, No. 1, Januari - Juni 2016 


\section{Parisipasi dalam Acara Kematian}

Begitu juga dengan peristiwa kematian, mereka warga pesantren dan segenap santrinya juga berpatisipasi, baik itu terlihat pada masa proses penguburannya sampai pada acara tahlilan di rumah keluarga yang meninggal tersebut. Hal ini berdasarkan wawancara dengan salah seorang Tokoh masyarakat, menyatakan bahwa para santri khususnya yang remaja dan dewasa banyak yang datang pada malam tahlilan. Baik pada malam pertama, malam kedua, malam ketiga dan malam ketujuhnya. ${ }^{24}$ Ini menunjukkan bahwa peranserta anggota pesantren, baik para santri , para guru-guru madrasah dan bahkan Ustaznya sendiri sangat tanggap dan apresisasi terhadap kegiatan ini.

Perubahan Sosial Keagamaan Masyarakat sekitar dengan Keberadaan pondok Pesantren Daruu Attauhid di Desa Moaro Kumpeh.

\section{Perubahan Keadaan Sosial}

Berdasarkan hasil observasi dan wawancara ditemukan bahwa sebelum berdirinya pesantren Daruu Attauhid di Desa Muaro Kumpeh Kecamatan Kumpeh Ulu Kabupaten Muaro Jambi keadaan sosial keagamaan masyarakat jauh berbeda dengan keadaan yang sekarang. Di mana dahulunya daerah ini terkenal dengan perilaku anak-anak mudanya yang kurang baik, hal tersebut terlihat dari segi perilaku keseharian, kebiasaan nongkrong atau kumpul-kumpul di tepi jalan, mabuk-mabukan dan perjudian.

Bahkan daerah ini terkenal dengan anak mudanya yang sering meminta secara paksa uang di jalanan kepada pengendara motor atau mobil. ${ }^{25}$ hal tersebut juga dibenarkan oleh Iwan seorang warga desa Pudak yang pernah mengalami aksi pemaksaan tersebut pada tahun 1999 lalu. ${ }^{26}$ Dia mengatakan bahwa waktu dahulu dia sering takut untuk melewati desa tersebut apalagi pada malam hari karena banyak anak-anak mudanya yang duduk nongkrong di pinggir jalan atau di jembatan. Namun sekarang sudah tidak kawatir lagi, mau jam berapa pun mereka melewati desa tersebut tidak ada yang akan

24 Hafiz, Wawancara dengan peneliti pada 5 Desember 2015 di desa Murao Kumpeh.

25 Yusuf, wawancara dengan peneliti pada 7 Desember 2015 di desa Muaro Kumpeh.

26 Iwan. Wawancara dengan peneliti pada 10 desember 2015 di desa Pudak.

TAJDID vol. XV, No. 2, Juli - Desember 2016|181 
mengganggunya. Sebab katanya keadaan sekarang anak mudanya tidak seperti dulu lagi. Tidak terlihat lagi anak-anak muda yang nongkrong dan mabuk-mabukan lagi. Apalagi setelah adanya pesantren Daruu Attauhid nampak sekali perubahan yang terjadi, terlihat banyak anakanak mudanya yang berpenampilan islami.

Jadi berdasarkan pengamatan dan hasil wawancara terhadap masyarakat terlihat bahwa keberadaan pesantren sebagai salah satu lembaga pendidikan agama Islam di desa Muaro Kumpeh ini memiliki peran yang sangat besar terhadap perubahan keadaan sosial masyarakat sekitarnya. Oleh karenanya Pondok pesantren selain sebagai lembaga pendidikan keagamaan (tafaqquh fiddin) juga berfungsi sebagai lembaga pengembangan sosial masyarakat, karena tumbuh dan berkembangannya ada ditengah-tengah masyarakat. Pengembangan potensi sosial diarahkan pada keamampuan pesantren dalam menganalisis sosial (Ansos), advokasi kepada yang lemah pada problem-problem yang terjadi di masyarakat, seperti keterbelakangan, kebodohan, kemiskinan, serta dekadensi sosial. ${ }^{27}$

Begitu juga dengan pesantren Daruu Attauhid, dengan sistem dan karakter tersendiri telah menjadi bagian integral dari suatu institusi sosial masyarakat, khususnya masyarakat desa Muaro Kumpeh. Bahkan beberapa diantaranya muncul sebagai model gerakan alternatif bagi pemecah masalah-masalah sosial masyarakat sekitar atau masyarakat desa. Seperti sekarang sudah jarang sekali terjadinya masalah-masalah sosial, seperti kemalingan, pengompasan, pengeroyokan dan sebagainya. Begitu juga kalau dahulu banyak kedaikedai yang menjual minuman keras tetapi sekarang tidak ada satupun toko di desa muaro Kumpeh yang menjual minuman keras tersebut, karena itu sudah menjadi aturan kampung untuk melarang penjualan miras. Walaupun tidak dinafikan ada segelintir anak-anak muda yang masih melakukan minum-minuman keras dan itu mereka lakukan secara sembunyi-sembunyi, dan mereka mendapatkannya atau membelinya dari desa lain.

Ajaran-ajaran yang dituturkan oleh ustaz Salahuddin telah membentuk pandangan, nilai-nilai, dan sikap hidup masyarakat kearah nilai-nilai Islami, walaupun pergeserannya tidak drastis. Keberadaan pesantren ditengah-tengah masyarakat dapat dijadikan pemecahan masalah sosial keagamaan masyarakat sekitarnya. Tidak dengan

27 Depag RI, Pedoman Pembinaan Pondok Pesantren dan Madrasah Diniyah, Jakarta: Ditjen Binbga Islam, 2005, hal. 33. 
strategi dan teori pembangunan yang digunakan pemerintah. Sebab gerakan pesantren dilandaskan pada ketauhidan, amal saleh, sebagai refleksi dari penghayatan dan pemahaman keberagamaan yang diajarkan oleh ustaz, sebagai pemimpimpin pesantren. Hal ini yang membuat pesantren Daruu Attauhid mempunyai keistemewaan tersendiri dalam melakukan kiprahnya, yang diperanani oleh Ustaz salahuddin, serta lingkungan sosial pada suatu ruang dan waktu tertentu. Namun, ada satu hal yang sama yang melandasi gerak tersebut, yaitu berangkat dari sikap dan keyakinan agama, serta orientasi pada masyarakat. Sebagai warga sekitar pesantren yang turut menjaga dan mengamalkan ajaran agama secara baik dan benar.

Adapun kontribusi-kontribusi yang diberikan oleh pondok pesantren Daruu Attauhid dalam pemenuhan kebutuhan dan tuntutan masyarakat yakni pondok pesantren mampu mencetak pribadi Muslim yang berpegang teguh pada Al-Qur'an dan Al- Hadits yang siap terjun di masyarakat, Hal ini bisa dicontohkan dari lulusan-lulusan pondok pesantren Daruu Attauhid yang tidak jarang menjadi tenaga pengajar, baik menjadi guru, atau setidaknya mereka menjadi tokoh-tokoh panutan masyarakat. Dengan menjadi tenaga pengajar, mereka dapat mengamalkan ilmu yang mereka punya, sekaligus juga bisa melakukan syiar-syiar agama Islam (dakwah). Sementara kemampuan membaca kitab kuning yang dimiliki oleh lulusan-lulusan dari pondok pesantren Daruu Attauhid, bisa dijadikan sebagai salah satu daya tarik tersendiri dalam melakukan syiar agama Islam di kalangan masyarakat Desa Muaro kumpeh.

\section{Perubahan Kesadaran Pengamalan Agama dalam Masyarakat di Desa Muaro Kumpeh}

Berbicara mengenai pengamalan keagamaan, bahwasanya antara individu satu dengan inividu lainnya berbeda. Hal ini desebabkan oleh perbedaan tingkat pengetahuan dan pemahaman serta kesadaran beragama manusia. Oleh karenanya sudah biasa dalam satu keluarga yang terdiri dari ayah, ibu dan anak memiliki kesadaran yang berbeda dan bahkan ada sesetengah dalam satu keluarga yang anggotanya memiliki agama dan keperyaan yang berbeda seperti yang terjadi pada beberapa artis tanah air.

Selain dilakukan pada lingkungan keluarga, yakni oleh orang tua, maka setelah tumbuh menjadi anak-anak kewajiban orang tualah untuk membina sifat, karakter, ahklak anak dalam keluarga baik itu dengan melalui pendidikan formal maupun non formal. Dengan

TAJDID vol. XV, No. 2, Juli - Desember 2016|183 
demikian diperlukan penanaman nilai-nilai agama pada individu sejak dini lagi. Selain itu juga diberikan pengetahuan tentang pendalaman agaman. Untuk itu diperlukan suatu lembaga pendidikan seperti pondok pesantren sebagai wadah penanaman pengetahuan dan nilai nilai keagamaan. Kehadiran pesantren dewasa ini telah memainkan perannya sebagai komponen pendidikan dalam masyarakat, meskipun masih dalam taraf yang perlu dikembangkan lebih lanjut.

Sebagai salah satu komponen pendidikan masyarakat, pesantren memiliki kekuatan dan ciri khas tersendiri untuk melakukan perubahan-perubahan yang berarti. Menyahut tantangan tersebut maka, inilah yang menjadi salah satu alasan didirikannya pondok pesantren Daruu Attauhid oleh Ustadz Salahuddin, yakni ingin memberikan pengetahuan ilmu agama terhadap masayarakat khususnya generasi muda sehingga nantinya mereka mempunyai arah dan tujuan hidup yang berpedoman pada al-Qur'an dan sunnah. ${ }^{28}$

Berdasarkan hasil observasi dan wawancara peneliti dilapangan maka ditemukan bahwa banyak perubahan-perubahan yang terjadi dalam masyarakat terhadap kesadaran pengamalan agama dalam kehidupan sosial masyarakat desa Muaro Kumpeh tersebut selama keberadaan pondok pesantren Daruu Attauhid tersebut. Adapun bentuk perubahan tersebut antaranya :

Untuk anak-anak; banyaknya para orang tua menyekolahkan anaknya di madrasah pondok, ada anggapan bahwa anak-anak tersebut jika tidak sekolah di madrasah, maka ia akan malu dengan teman-temannya. Kemudian tingkat kesadaran anak-anak untuk melakukan ibadah cukup baik seperti melaksanakan shalat lima waktu di rumah.

Untuk para remaja; mereka cukup antusias untuk mengamalkan ajaran agama. Hal ini terlihat, dahulunya masih banyak para remaja yang duduk dan ngumpul-ngumpul di tepi jalan atau di warung, namun sekarang sudah jarang sekali. Banyak diantara mereka yang mengaji di pondok tersebut. begitu juga dalam situasi keseharian berdasarkan pengamatan terlihat suasana lingkungan cukup agamis hal tersebut terlihat dari cara berpakain mereka.

Untuk warga dewasa; memang sudah banyak perubahan, namun perubahan tersebut tidaklah signifikan. Hal ini terlihat dari pantauan

${ }^{28}$ Salahuddin, wawancara dengan peneliti pada 12 Desember 2016 di desa Muaro Kumpeh.

184 | TAJDID vol. XV, No. 1, Januari - Juni 2016 
peneliti sebagai contoh masih kurangnya minat atau kesadaran para warga untuk shalat berjamaah di masjid terlihat cukup banyak di dominasi oleh anak muda, kususnya pada waktu magrib, isya atau pun subuh. Terlihat hanya beberapa orang saja yang shalat berjamaah. Lain halnya di mushollah pondok memang ramai, semua santri diharuskan shalat berjamaah.

Kemudian daripada itu, menurut Hamid, ${ }^{29}$ mengatakan bahwa semenjak adanya pesantren Daruu Attauhid di desa mereka sangat berdampak sekali. Dalam keterangannya mengatakan bahwa dahulunya sebelum keberadaan pesantren tersebut keadaan sosial keagamaan masyarakat khususnya kalangan anak-anak muda sangat kurang. Dimana para remaja dahulu masih suka melakukan perbuatan-perbuatan yang menyalahi aturan seperti meminum minuman keras, berjudi dan sering terjadi konflik. Akan tetapi sekarang boleh dikatakan sangat jarang terjadi, walaupun masih ada segelintir yang belum berubah. Namun menurutnya hal tersebut biasa, yang terpenting sekarang perubahannya dirasakan oleh masyarakat, yakni nampak sekali suasana yang cukup islami pada keadaan masyarakat sekitar pondok pesantren Daruu Attauhid.

\section{Kesimpulan}

Berdasarkan hasil pengamatan dan wawancara peneliti terhadap kepala desa, tokoh masyarakat, pimpinan, pengajar, dan masyarakat, maka penulis mendapatkan informasi tentang karakteristik pondok pesantrenDaruu Attauhid adalah : Pesantren Daruu Attauhid adalah tergolong pada pesantren Salafiyah, sehingga kurikulum pembelajarannya tidak mengikuti aturan atau pedoman yang ada pada Kemenag atau Kemendiknas, akan tetapi pesantren tersebut memiliki acuan pembelajaran sendidi. Pembelajaran (pendidikan dan pengajaran) yang ada pada pondok pesantren ini dapat diselenggarakan dengan cara non-klasikal atau dengan klasikal. Terdapat beberapa tingkatan pembelajaran yakni pada tingkat Madrasah Ibtidaiyah, Madrasah Tsanawiyah dan santri Kalong.

Adapun Hubungan Sosial Pondok Pesantren Daruu Attauhid dengan Masyarakat Sekitar adalah sangat erat. Masyarakat menyaambut dengan baik dengan adanya pesantren tersebut, karena anak-anak mereka dapat menimba ilmu agama disana. Sekarang ini

29 Hamid. Wawancara dengan peneliti pada 2 Desember 2015 di desa Muaro Kumpeh .

TAJDID vol. XV, No. 2, Juli - Desember 2016 |185 
menjadi lulusan pesantren atau madrasah menjadi sebuah kebanggaan tersendiri bagi orang tua dan masyarakat. Partisipasi pesantren juga terlihat dalam Kegiatan Peringatan Hari Besar Islam seperti Maulid Nabi Muhammad Saw, Peringatan Isra'walmi'raj, Tahun Baru Hijriah, Nuzulul Qur'an dan sebagainya. Mereka mengikuti acara yang diadakan oleh masayarakat kampung, selain itu mereka juga mengadakan sendiri dan mengundang masyarakat desa Muaro umpeh tersebut.

Begitu juga terhadap Perubahan Sosial Keagamaan Masyarakat sekitar dengan Keberadaan pondok Pesantren Daruu Attauhid di Desa Moaro Kumpeh. Adapun bentuk perubahan keadaan Sosial ditemukan bahwa sebelum berdirinya pesantren Daruu Attauhid di Desa Muaro Kumpeh Kecamatan Kumpeh Ulu Kabupaten Muaro Jambi keadaan sosial keagamaan masyarakat jauh berbeda dengan keadaan yang sekarang. Di bidang pendidikan dahulunya masih sedikit sekali anak-anak yang bersekolah madrasah, begitu juga dalam hal keadaan sosial di mana dahulunya daerah ini terkenal dengan perilaku anak-anak mudanya yang kurang baik, hal tersebut terlihat dari segi perilaku keseharian, kebiasaan nongkrong atau kumpul-kumpul di tepi jalan, mabuk-mabukan dan perjudian. Namun sekarang tidak terlihat lagi anak-anak muda yang nongkrong dan mabuk-mabukan lagi dan terlihat banyak anak-anak mudanya yang berpenampilan islami. Jadi berdasarkan pengamatan dan hasil wawancara terhadap masyarakat terlihat bahwa keberadaan pesantren sebagai salah satu lembaga pendidikan agama Islam di desa Muaro Kumpeh ini memiliki peran yang sangat besar terhadap perubahan keadaan sosial masyarakat sekitarnya. Ajaran-ajarannya telah membentuk pandangan, nilai-nilai, dan sikap hidup masyarakat kearah nilai-nilai Islami. walaupun pergeserannya tidak drastis. Namun keberadaan pesantren ditengahtengah masyarakat dapat dijadikan pemecahan masalah sosial keagamaan masyarakat sekitarnya dan memanamkan ajaran agama dengan baik dan benar.

\section{Daftar Pustaka}

Anonim. Al-Qur'an dan Terjemahannya, Surabaya: Departemen Agama RI.1989.

Abasari.(2009). Sejarah dan Dinamika Lembaga-Lembaga Pendidikan Islam di

Nusantara, dalam Sejarah Pendidikan Islam. Jakarta: Kencana. 2009.

186 | TAJDID vol. XV, No. 1, Januari - Juni 2016 
Abdullah Syukri Zarkasyi, Gontor dan Pembaharuan Pendidikan Pesantren, Jakarta: PT. Raja Grafindo Persada, 1996.

Amin Haedari, (2008), Peningkatan Mutu Terpadu Pesantren dan Madrasah Diniyah, Jakarta : Diva Pustaka.

Budhy Munawar-Rahman. Pendidikan Karater; Pendidikan Menghidupkan Nilai Untuk Pesantren, Madrasah, dan sekolah. 2015

Depag RI, Pola Pengembangan Pondok Pesantren, Jakarta: Ditjen Binbaga Islam, 2003.

Depag RI, Pedoman Pembinaan Pondok Pesantren dan Madrasah Diniyah, Jakarta: Ditjen Binbga Islam, 2005.

Direktorat Jenderal Kelembagaan Agama Islam, Jakarta, 2005.

Faiqoh, Pondok Pesantren dan Madrasah Diniyab: Pertumbuban dan perkembangannya, Jakarta: Depag RI, 2004.

Henslin, James M. Essential of Sociology : A Down-to-Earth Approach (Sosiologi dengan Pendekatan Membumi). Penerjemah: Kamanto Sunarto. Jakarta: Penerbit Erlangga.2007.

Hasbullah, Kapita Selekta Pendidikan Islam, Jakarta: PT. Raja Grafindo Persada, 1996.

Hasbullah. Sejarah Pendidikan Islam di Indonesia: Lintasan Sejarah. Pertumbuhan dan Perkembangan. Jakarta: PT. Raja Grafindo Persada 1999.

http://www.artikata.com/arti-206483-zaman.htm

http://referensiagama.blogspot.com/2011/01/teori-perubahansosial.html

Kasful Anwar. Kepemimpinan Kyai Pesantren (Studi pada Pondok Pesntren di Kota Jambi). Disertasi. Bandung: 2010.

Khoirul Ihwanudin. Peran Pesantren Terhadap Perubahan Sosial Masyarakat. Di akses https://pondpestalhidayah.wordpress.com/2011/06/10/peranpesantren-terhadap-perubahan-sosial-masyarakat/

Manfred Ziemek, Pesantren Dalam Perubahan Sosial, Alih Bahasa: Butch B.Soendjojo, Jakarta: P3M, 1986.

Matthew B. Miles \& A. Michael Huberman, Analisis Data Kualitatif: Buku Sumber Tentang Metode-Metode Baru. Jakarta: UI-Pres, 1992. Mubtarom HM dalam Ismail et.al. (ed), Dinamika Pesantren dan Madrasah, Yogyakarta : Pustaka Pelajar.2002.

TAJDID vol. XV, No. 2, Juli - Desember 2016|187 
Muhammad Ansoridin Sidiq. Pengembangan Wawasan IPTEK Pondok Pesantren. Jakarta: Amzah. 2000.

Partanto, Pius A dan M. Dahlan al Barry. Kamus Popular Ilmiah. Surabaya:Penerbit Arkola, 1994.

Peraturan Menteri Agama Republik Indonesia Nomor 13 Tahun 2014 tentang Pendidikan Keagamaan Islam.

Sihabuddin. Pesantren sebagai Agent of Change. Di akses https://ayikngalah.wordpress.com/2011/07/21/peran-

pesantren-dalam-pemberdayaan-masyarakat/

Sugiono, Metode Penelitian Manajemen; Pendekatan Kuantitatif, Kualitatif, Kombinasi, Penelitian Tindakan, dan Penelitian Evaluasi, Bandung: Alfabeta, 2014.

Sugiono, Metode Penelitian Pendidikan: Pendekatan Kualitatif, Kuantitatif dan R \& D, Bandung: Alfabeta, 2014.

Sulthon Masyhud, (2003), Manajemen Pondok Pesantren, Jakarta : Diva. 2005.

Yasmadi, Modernisasi Pesantren, Krituk Nurcholish Madjid terhadap Pendidikan Islam Tradisional, Edisi Revisi, Ciputat: Quantum Teaching, 2002.

Wahjotomo, Perguruan Tinggi Pesantren, Pendidikan Alternatif Masa Depan Jakarta: Gema Insani Press, 1997

Zamakhsyari Dhofier, Tradisi Pesantren Studi tenang Pandangan Hidup Kyai, Jakarta: LP3ES. 1994 